\title{
Levels of reading comprehension questions in EFL classroom: higher order thinking skills (HOTS)
}

\author{
Y Zainil ${ }^{1}$, M S Lena ${ }^{2}$ \\ \{yettizainil@fbs.unp.ac.id\} \\ ${ }^{1}$ Universitas Negeri Padang Jln Prof. Hamka, Air Tawar, Padang, Indonesia
}

\begin{abstract}
This paper presents the discussion on the teachers' reading comprehension questions in EFL classrooms of Senior High Schools in Padang. Higher-order thinking skill has become a significant theme in education. However, to what extent EFL teachers have applied it, does not clearly define yet. In the English language learning process, the students are encouraged to think critically. Therefore, teachers are required to provide the students with higher-order thinking skill, especially in reading comprehension. The higher level of reading comprehension questions can facilitate students' higher-order thinking skills. Many studies have revealed that the level of teacher questions determines the level of thinking of students. However, until now, most of the questions asked by teachers in the context of English as a foreign language (EFL) were low-level questions. Those questions were not as effective as high-level questions in helping students develop high-level thinking skills. Therefore, EFL teachers should ask different types of questions at each grade level.
\end{abstract}

Keywords : Comprehension, Questions, HOTS

\section{Introduction}

In the current industrial 4.0 era, developing high-level thinking, especially critical thinking, problem-solving, and reasoning, is crucial. For this reason, the learning process in the classroom changes to focus more on the learning process than the final product; students are encouraged to think critically. They have to think more to solve their problems. Therefore, the teachers are required to facilitate students by providing skills to acquire high-level thinking, also known as 'high order thinking skills' (HOTS).

In the learning process, mostly the pattern of interaction between teachers and students that occurs takes the form of teacher asking questions [1]. Research showed that the average question posed by a teacher per day reaches 80 percent of the utterances used by the teacher [2] Concerning the question, Zainil discusses that the level of questions asked by the teacher determines the level of thinking of students [3]. However, classroom studies reveal that teachers use lower-level questions far more than high-level questions [4] [5].

Besides analysing the questions based on Widdowson's theory was found that most of the questions in the two books which were used by English teachers in class XI in one of the public secondary schools in Padang in the low level of questions [6]. A study on questioning strategies was conducted in SMA Negeri in Gowa, Makasar; the results of the study shows that teachers asked open/closed questions and display questions. Only a few referential questions were asked by those teachers [7]. In line with this, several high schools in the city of 
Padang have applied HOTS in the learning process, especially in English subjects. However, research revealed that only 36 out of 173 reading comprehension questions in textbooks used in class $\mathrm{X}$ in one of the public high schools in Padang that met the HOTS category [4]

\section{The order of thinking skills}

The level of comprehension shows that the learners understand what they have read [8]. It reveals when the students can retell, interpret, explain, predict, and outline knowledge of a certain thing. The questions aiming to elicit a student's understanding of the material are those that ask the learner to interpret, exemplify, classify, summarize, infer, compare, and explain. In this level, teachers may ask students the conclusion of video-tape that they have watched, or teachers ask students to compare the historical event to the contemporary situation.

The application questions obligate the learner to execute a procedure or process, mental or physical, to an unfamiliar condition or circumstance [5]. It is the phase of the student to employ their intelligence in a new situation. It reveals at the same time the students demonstrate, implement, carry out, or describe an identical situation. For example, when teachers ask students to use appropriate respond in a specific situation is the example of application questions.

Analysis is identified as the process of breaking the information into small parts identifying motives or causes[9]. It occurs when the learners compose the information and relate their prior knowledge. Analysis questions ask the students to organize the elements within a structure, distinguish relevant from irrelevant information, or deconstruct underlying values and biases [8]. Another possibility in analyzing questions is when students are asked to differentiate pertinent from impertinent parts or important from unimportant parts of provided materials [10]. The example is when the teacher asks students to determine the viewpoint of the author of an essay in terms of their political context.

Evaluation question requires the student to criticism a work or product, assign the appropriateness of a process or product for a given problem, or examine the inconsistencies in theory. Evaluating means developing the reason to support resolution [8]. It happens when the student judges, chooses, recommends, justifies, critics the text, such as the teacher asks students to judge what is the best way to solve a problem.

Creation as the highest level is examined as the most challenging responsibility in terms of cognitive processing. The questions, which address this cognitive domain, may require students in generating alternative hypotheses. These are based on observed phenomena, design a new procedure to accomplish a task, or conceptualize a new product. It appears when the students design, construct, plan, and produce new ideas [8]. In the level of creating, the teacher may ask students to plan a research paper based on a given linguistic topic. The teacher can also ask students to generate hypotheses to explain for an observed phenomenon.

The modification was made to Bloom's original structure of thinking. Anderson and Krathwohl changed the heading of each level from nouns to a verb. The synthesis level in the higher level is replaced by evaluating. And evaluation of Bloom's top Level 1 is substituted by creating [10]. Anderson and Krathwohl propose higher-order thinking skills and low order thinking skills [10]. The top three levels reflect these (Analyzing, Evaluating, and Creating) for high order thinking skills and Remembering, Understanding, and Applying for lower-order thinking skills [10] 
It is crucial to the teacher to have the capability of understanding learning taxonomy. By having that understanding, it will help the teacher in digging students' cognitive domain. This domain can be a guideline for the teacher to assess the learning process. It is then highlighted that the cognitive domain includes thinking skills. The theory of thinking skills will help the teacher in constructing the questions. By knowing the theory of thinking skills, teachers will be able to assess how far their students' comprehension.

The revised Bloom's cognitive domain describes the six processes of cognitive with a view of how teachers use these cognitive process to classify the level of questions and prepare the questions [10]. The levels of questions are detached into two parts; lower level and higher level. Lower levels of the question consist of remembering, understanding, and applying questions. Meanwhile, higher levels of question are questions in the level of analyzing, evaluating, and creating.

\section{Levels of questions}

It is a fact that the teacher's utterance dominates the classroom, and the teacher's words influence student learning. Teacher's statements can be in the form of corrections (feedback), confirmation (confirmation), and questions [1]. However, often, teachers' questions do not demand the students to think critically in answering those questions. In other words, teachers often provide questions in a low level of thinking $[4,5]$.

High order thinking skills involve the alteration of information and ideas [11]. This transformation occurs when students analyze, combine facts and ideas, synthesize, generalize, explain, or arrive at conclusions or interpretations. Furthermore, by analyzing information and ideas helps students to solve problems, gain understanding, and discover new meanings. Students were expected to think critically in capturing the information and ideas. Meanwhile, low-level thinking skills require students to memorize or remember facts [12]. The higherlevel thinking skills are enabling the students to compose meaning by combining facts, drawing conclusions and explaining or hypothesizing [10] [11] [12]. As discussed previously, one of the ways to encourage learners in getting higher-order thinking skills is the teacher giving the questions. Thus, a teacher is required to be able to guide their students to have highlevel thinking skills by asking high level of questions. For this reason, the teacher needs to understand the level of questions they ask.

Teachers often use questions to assure that students are paying attention and involved as well as assessing student understanding. For example, to ascertain that students are paying attention, a teacher can ask students "Are you listening?" or to assess students' knowledge, the teacher can ask, "Have you understood?" Learners may answer, "Yes, I listen" or "Yes, understand ma'am, just to avoid shyness. Let us compare the questions "are you listening" or "have you understood" with the questions that ask students to summarize what they read; or ask students for opinions about what was discussed. The difference in the level of these questions is that despite the intent questions remain the same, high-level and open-ended questions allow the teacher to evaluate more accurately whether students are truly pay attention to the teacher and whether they understand the material.

Furthermore, open questions or high-level questions may motivate students to think critically, allowing students to share their ideas. The thinking skills proposed by Bloom were classified into two categories, namely low-level thinking skills consisting of the ability to remembering, understanding and applying (LOTS) and high-level thinking skills consisting 
from analyzing, evaluating, and creating (HOTS) [10] [13]. Moreover, indicators for measuring high-level thinking skills include: analyzing, evaluating, and creating [10] [13].

Omari discusses that when someone faces unfamiliar problems, uncertainties, questions, or dilemmas; thus, these will activate the ability of higher-order thinking skills [14]. If these skills are well developed and then, maintained that individual could make better decisions as well as grow their intellectual skills [15]. The development of higher-order thinking skills depends on someone's lower level thinking skills; thus making higher-order thinking skills grounded with lower-level thinking skills. Consequently, to be able to think critically, previous knowledge of subject matter content is necessary.

Related to the developing of a test, teachers have to use questions as a tool to evaluate students' knowledge, comprehension, and critical thinking [5]. Questions can be given in the written or oral form. For instance, teachers may test their students by giving them a passage that is followed by several questions. In order to know how their comprehension and their critical thinking about the passage are the questions of the passage should be able to dig students' critical thinking [8]. One of the solutions to get students' knowledge deeply is by using higher levels of questions in the passage. Higher-level of questions will stimulate students' higher level of thinking in constructing responses [5].

Since higher levels of questions bring out students' critical thinking, teachers are encouraged to ask questions in these domains. However, it does not mean that lower levels of questions are not appropriate to be asked. Teachers may be able to use questions with all cognitive domains as long as the test items have a good combination of the cognitive domain. The table 1 below presents the keywords for the level of the questions.

Table 1. Keyword for the level of the questions

\begin{tabular}{|c|c|}
\hline Levels of Question & Keywords \\
\hline $\begin{array}{l}\text { Remembering: can the student } \\
\text { retrieve the relevant knowledge } \\
\text { from long term memory? } \\
\text { Understanding: can the student } \\
\text { construct meaning from } \\
\text { instructional messages? }\end{array}$ & $\begin{array}{l}\text { Define, recognize, identify, retrieve, } \\
\text { duplicate, list, memorize, recall, repeat, } \\
\text { state, locate. } \\
\text { Interpret, clarify, paraphrase, represent, } \\
\text { translate, exemplify, illustrate, instantiate, } \\
\text { classify, categorize, subsume, abstracting, } \\
\text { generalize, conclude, extrapolate, describe, } \\
\text { discuss, explain, identify, report, select. }\end{array}$ \\
\hline $\begin{array}{l}\text { Applying: can the student use a } \\
\text { procedure in a given situation? }\end{array}$ & $\begin{array}{l}\text { Carry out, demonstrate, dramatize, employ, } \\
\text { illustrate, operate, schedule, sketch, solve, } \\
\text { use, write. }\end{array}$ \\
\hline $\begin{array}{l}\text { Analyzing: can the student break } \\
\text { material into its constituent parts, } \\
\text { distinguish or connect the } \\
\text { different parts based on a certain } \\
\text { structure? }\end{array}$ & $\begin{array}{l}\text { Differentiate, discriminate, distinguish, } \\
\text { focus, select, organize, find the coherence, } \\
\text { integrate, outline, structure, attribute, } \\
\text { deconstruct, compare, contrast, } \\
\text { differentiate, and discriminate. }\end{array}$ \\
\hline $\begin{array}{l}\text { Evaluating: can the student make } \\
\text { judgment based on criteria and } \\
\text { standard? }\end{array}$ & $\begin{array}{l}\text { Check, coordinate, detect, monitor, test, } \\
\text { argue, defend, judge, select, value, evaluate. }\end{array}$ \\
\hline $\begin{array}{l}\text { Creating: can the student create or } \\
\text { put elements together or } \\
\text { reorganize elements into new } \\
\text { pattern or structure? }\end{array}$ & $\begin{array}{l}\text { Generate, hypothesize, plan, design, } \\
\text { procedure, construct, assemble, create, } \\
\text { design, develop, formulate, reorganize or } \\
\text { rewrite. }\end{array}$ \\
\hline
\end{tabular}

${ }^{\mathrm{a}}$ Anderson and Krathwohl [10] 


\section{Conclusion}

Bloom was the first expert to propose the learning taxonomy. Andersen et al. revised this taxonomy. Teachers can use this taxonomy as a guideline in creating questions to assess their students' knowledge. Anderson et al. identify the structures of cognitive taxonomies into six; remember, understand, apply, analyze, evaluate, and create. Questions that bring out responses in remembering, understanding, and applying are considered as lower levels of questions (LOTS), meanwhile, questions in analyzing, evaluating, and creating level are considered as higher-level of questions (HOTS). Teachers are suggested to use higher-level questions as a tool to assess students' understanding, comprehension, and to enhance students' critical thinking skills.

\section{References}

[1] L F Faruji 2011 Theory \& Practice in Language Studies 111

[2] Levin T and Long R 1981 Effective Instruction. Association for Supervision and Curriculum Development (Alexandria: eric)

[3] Y Zainil 2004 Aplikasi Tehnik bertanya pada Mata Kuliah Intensive Course Universitas Negeri Padang (Padang:Universitas Negeri Padang\}

[4] N H Damanik and Y Zainil 2019 Journal of English Language Teaching 8249

[5] T Tofade, J Elsner and S T Haines 2013 American journal of pharmaceutical education 77155

[6] E Fitria and H Syarif English Language Teaching (ELT) 220

[7] Sujariati S, Rahman A Q and Mahmud M 2016 ELT WORLDWIDE 3107

[8] Dagostino L, Carifio J, Bauer J D, Zhao Q and Hashim N H 2015 Current Issues in Education 18 2

[9] B S Bloom 1956 Taxonomy Of Educational Objectives (New York: McKay)

[10] L W Anderson and Krathwohl D R 2001 A Taxonomy for Learning, Teaching and Assessing: A Revision of Bloom's Taxonomy of Educational Objectives (New York: Longman)

[11] A S Keshta and A Seif Asian 2013 Journal of Education and e-Learning 11

[12] T Gunning 1996 Creating Reading Instruction For All Children (USA: Allyn and Bacon Publishing)

[13] D L Schwartz, C C Chase, M A Oppezzo and D B Chin 2011 Journal of Educational Psychology 103759

[14] H A Omari 2018 Modern Applied Science 1210

[15] W Widana 2017 Penyusunan Soal High Order Thinking Skills (Jakarta: Departemen Pendidikan dan Kebudayaan) 